\title{
Phosphoenolpyruvate Mutase Catalysis of Phosphoryl Transfer in Phosphoenolpyruvate: Kinetics and Mechanism of Phosphorus-Carbon Bond Formation $^{\dagger}$
}

\author{
Jaebong Kim and Debra Dunaway-Mariano* \\ Department of Chemistry and Biochemistry, University of Maryland, College Park, Maryland 20742 \\ Received December 13, 1995; Revised Manuscript Received February 13, $1996^{\otimes}$
}

\begin{abstract}
Phosphoenolpyruvate phosphomutase (PEP mutase) from Tetrahymena pyriformis catalyzes the rearrangement of phosphoenolpyruvate (PEP) to phosphonopyruvate (P-pyr). A spectrophotometric P-pyr assay consisting of the coupled actions of P-pyr decarboxylase, phosphonoacetaldehyde hydrolase, and alcohol dehydrogenase was devised to monitor mutase catalysis. The reaction constants determined for PEP mutase catalyzed conversion of PEP to P-pyr at $\mathrm{pH} 7.5$ and $25^{\circ} \mathrm{C}$ in the presence of $\mathrm{Mg}(\mathrm{II})$ are $k_{\text {cat }}=5 \mathrm{~s}^{-1}, K_{\mathrm{m}}=0.77 \pm 0.05 \mathrm{mM}$, and $K_{\mathrm{eq}}=(2-9) \times 10^{-4}$. In the PEP forming direction, $k_{\text {cat }}=100$ $\mathrm{s}^{-1}$ and $K_{\mathrm{m}}=3.5 \pm 0.1 \mu \mathrm{M}$. Retention of stereochemistry at phosphorus and strong inhibition displayed by the pyruvyl enolate analog, oxalate, have been cited as two lines of evidence that PEP mutase catalysis proceeds via a phosphoenzyme-pyruvyl enolate intermediate [Seidel, H. M., \& Knowles, J. R. (1994) Biochemistry 33, 5641-5646]. In this study, single turnover reactions of oxalyl phosphate with the PEP mutase were carried out to test the formation of the phosphoenzyme intermediate. If formed, the phosphoenzyme-oxalate complex should be sufficiently stable to isolate. Reaction of the mutase with $\left.{ }^{32} \mathrm{P}\right]$ oxalyl phosphate in the presence of $\mathrm{Mg}(\mathrm{II}) / \mathrm{Mn}(\mathrm{II})$ cofactor failed to produce a detectable level of the $\left.{ }^{[2} \mathrm{P}\right]$ phosphoenzyme-oxalate complex. In contrast, the same reaction carried out with pyruvate phosphate dikinase (PPDK), an enzyme known to catalyze the phosphorylation of its active site histidine with PEP, occurred at a rate of $4 \times 10^{-4} \mathrm{~s}^{-1}$ (15\% E-P formed) in the presence $\mathrm{Mg}(\mathrm{II})$ and at a rate of $3 \times 10^{-3} \mathrm{~s}^{-1}$ (60\% E-P formed) in the presence of $\mathrm{Mn}(\mathrm{II})$. Both oxalyl phosphate $\left(K_{\mathrm{i}}=180 \pm 10 \mu \mathrm{M}\right)$ and oxalate $\left(K_{\mathrm{i}}=32 \pm 10 \mu \mathrm{M}\right)$ were competitive inhibitors of PEP mutase catalysis, but neither displayed slow, tight binding inhibition. These results do not support the intermediacy of a phosphoenzyme-pyruvyl enolate complex in PEP mutase catalysis.
\end{abstract}

Naturally occurring phosphonates are believed to be the legacy of reduced forms of phosphorus present on earth prior to the formation of the present, oxygen-based, atmosphere (Mastelerz, 1984). Phosphonates are found in a wide variety of organisms, but their physiological roles in these organisms are not yet known (Horiguchi \& Kandatsu, 1959; Hildebrand, 1983; Hildebrand et al., 1983; Hori et al., 1984; Mastelerz, 1984). Phosphonates which are produced in bacteria as secondary metabolites vary widely in structure. Phosphonates produced in eucaryotes primarily consist of (2aminoethyl)phosphonate (AEP) ${ }^{1}$ and its N-alkylated derivatives. These structures are found covalently linked to cellular lipids, glycolipids, and proteins. The physiological roles of these phosphonate macromolecules have not yet been demonstrated; however, the concentration of the phosphonates at cell surfaces, particularly in nervous tissue, suggests that they may be important for cell signaling (Abe et al., 1991).

\footnotetext{
$\dagger$ This work was supported by NIH Grant GM 36260.

* To whom correspondence should be addressed.

${ }^{\otimes}$ Abstract published in Advance ACS Abstracts, March 15, 1996.

${ }^{1}$ Abbreviations: PEP, phosphoenolpyruvate; CPEP, carboxyphosphoenolpyruvate; P-pyr, phosphonopyruvate; P-ald, phosphonoacetaldehyde; AEP, (2-aminoethyl)phosphonate; P-Ala, phosphonoalanine; PLP, pyridoxal phosphate; ADH, alcohol dehydrogenase; LDH, lactate dehydrogenase; PK, pyruvate kinase; MDH, malate dehydrogenase; PPDK, pyruvate phosphate dikinase; NADH, dihydronicotinamide adenine dinucleotide; TPP, thiamin pyrophosphate; Hepes, $N-(2-$ hydroxyethyl)piperazine- $N^{\prime}$-2-ethanesulfonic acid; Mes, 2-( $N$-morpholino)ethanesulfonic acid; Tris, tris(hydroxymethyl)aminomethane; E-P, phosphorylated enzyme; NMR, nuclear magnetic resonance.
}

The study of phosphonate metabolism (Horiguchi, 1972; Barry et al., 1988; Seto et al., 1991; Hidaka et al., 1992, 1989; Hammerschmidt, 1991; Kuzuyama et al., 1992; Seto, 1986; Hara et al., 1991; Kamigiri et al., 1992) is a relatively new field for which there is a rapidly growing interest. The synthesis of phosphonates relies on phosphate precursors and on enzyme mediated chemistry which converts the $\mathrm{P}-\mathrm{O}$ bond to the $\mathrm{P}-\mathrm{C}$ bond. The chemical strategy that we have seen unfold thus far involves intramolecular oxygen to carbon phosphoryl transfer in vinyl phosphate esters. This chemistry is exemplified by the catalysis of PEP mutase (Bowman et al., 1988) and its close relative, CPEP mutase (Hidaka et al., 1989).

This paper describes the kinetics and mechanism of catalysis of $\mathrm{P}-\mathrm{C}$ bond formation by the PEP mutase of Tetrahymena pyriformis. First isolated from this protozoan (Bowman et al., 1988; Seidel et al., 1988), PEP mutase has since been purified from bacteria (Hidaka et al., 1989, 1992) and salt water mussel (Kim, 1994). In vivo, the mutase functions in the synthesis of P-pyr, the first of three reactions leading from PEP to AEP (Scheme 1). Because the equilibrium position of this reaction favors PEP (Bowman et al., 1988), catalysis by the mutase has been studied exclusively in the PEP-forming direction (Bowman et al., 1990; McQueney et al., 1991; Seidel et al., 1990, Seidel \& Knowles, 1994). The kinetic constants describing PEP mutase functioning in the physiological role of phosphonate synthesis have not been determined owing to the lack of a suitable assay. The first goal of the present work was to 
Scheme 1: Reaction Steps of the AEP Biosynthetic Pathway ${ }^{a}$

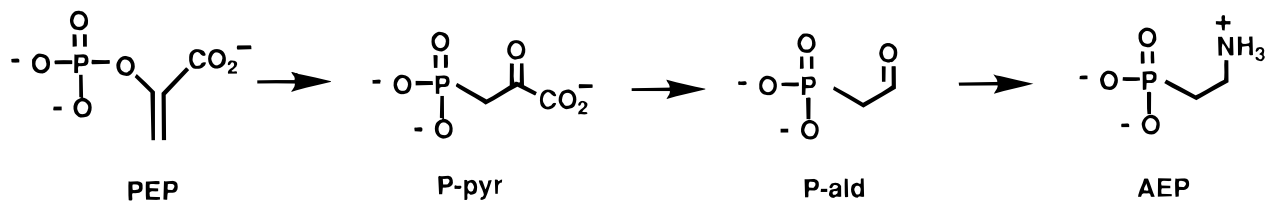

${ }^{a}$ The first step is catalyzed by PEP mutase, the second step by phosphonopyruvate decarboxylase, and the third step by phosphonoacetaldehyde transaminase (Bowman et al., 1988; Horiguchi, 1972).

Scheme 2: Illustration of Two Stepwise Mechanisms of PEP Mutase Catalysis under Consideration: (A) A Double Displacement Mechanism in Which the Phosphoryl Group Is First Transferred to an Enzyme Active Site Residue Forming Pyruvyl Enolate and Hence to the C(3) of That Enolate and (B) a Dissociative Mechanism in Which an Enzyme Complex of Pyruvyl Enolate and Metaphosphate Is Formed as the Reaction Intermediate

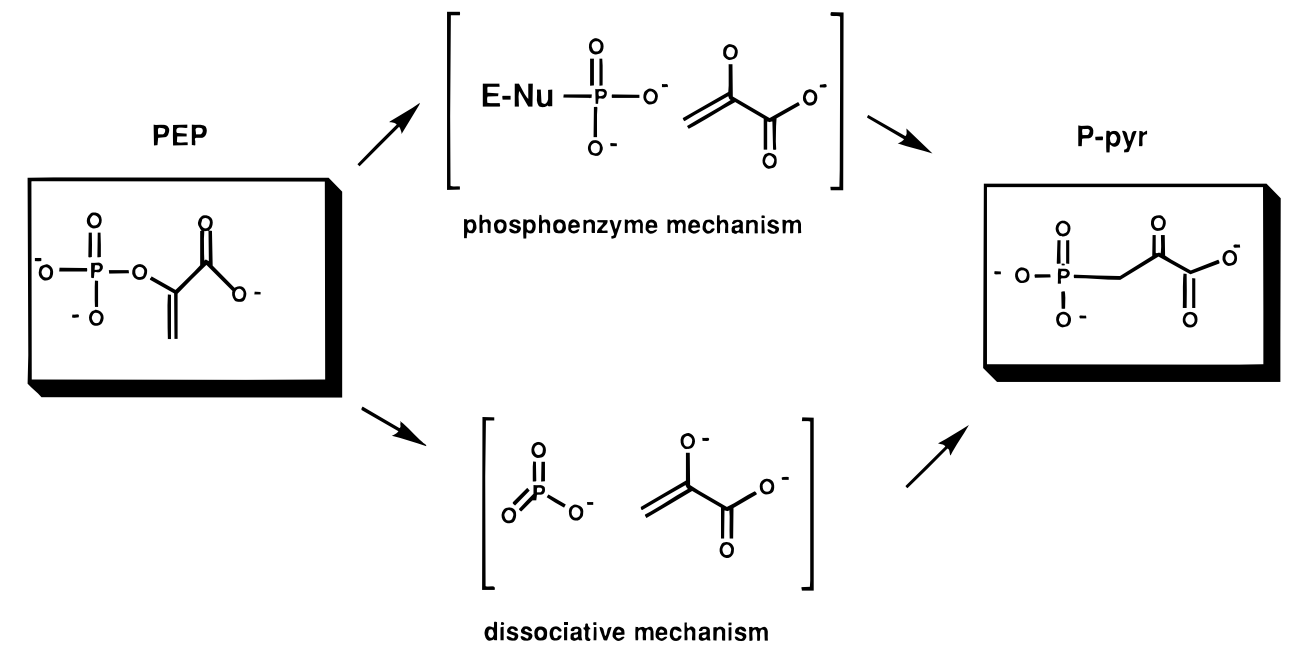

develop a method to assay the P-pyr-forming reaction catalyzed by PEP mutase in vitro and apply it to the determination of the equilibrium constant $\left(K_{\mathrm{eq}}\right)$ of the reaction and the kinetic constants of enzyme catalysis $\left(K_{\mathrm{m}}, k_{\text {cat }}\right.$ for PEP turnover).

The second goal of this work was to examine the chemical mechanism of the PEP mutase reaction. Previous studies have shown that PEP mutase catalyzed phosphoryl transfer occurs intramolecularly (McQueney et al., 1991) and with retention of stereochemistry at phosphorus (McQueney et al., 1991; Seidel et al., 1990). Hence, the reaction takes place by a stepwise mechanism. Three such mechanisms have been proposed: one in which the phosphoryl group is passed from substrate to enzyme and then back again (the phosphoenzyme mechanism), one in which the phosphoryl group is passed to the carboxyl group of the substrate and then to $\mathrm{C}(3)$ (the substrate-assisted mechanism), and one in which the phosphoryl group first dissociates from the PEP as metaphosphate and is then captured by $\mathrm{C}(3)$ of the pyruvyl enolate (the dissociative mechanism) (Seidel et al., 1990). The phosphoenzyme and dissociative mechanisms are distinguished from the substrate-assisted mechanism by the formation of an intermediate complex containing pyruvyl enolate (see Scheme 2). Seidel and Knowles (1994) have recently reported that oxalate, which is a low-energy structural/electronic analog of the pyruvyl enolate (Schmitt et al., 1966; Nova et al., 1959; Mildvan et al., 1966; Reed \& Morgan, 1974; Janc et al., 1992; Kofron et al., 1988; Michaels et al., 1975), binds to the mutase considerably tighter than does its substrate, PEP $\left(\mathrm{K}_{\mathrm{d}}=25 \mu \mathrm{M}\right.$ vs $\mathrm{K}_{\mathrm{d}}=$ $350 \mu \mathrm{M}){ }^{2}$ In addition, small planar anions were shown to enhance binding in the enzyme-oxalate complex presumably by filling the site which, during catalytic turnover, would be occupied by the phosphoryl group (Seidel \& Knowles, 1994). Thus, it can argued that PEP mutase catalysis proceeds via a pyruvyl enolate anion intermediate, hence by either the dissociative or phosphoenzyme mechanisms of Scheme 2. Citing the fact that the phosphoenzyme mechanism has known precedent in other enzyme-catalyzed phosphoryl transfer reactions while the dissociative mechanism does not, Seidel and Knowles (1994) largely dismissed the dissociative mechanism in favor of the phosphoenzyme mechanism.

In principle, the two mechanisms of Scheme 2 can be distinguished (experimentally) by using radiolabeled substrate in conjunction with rapid quench techniques to trap and identify the reaction intermediate (captured as phosphorylated enzyme plus pyruvate or phosphate plus pyruvate, respectively), provided that a sufficient quantity of intermediate accumulates on the enzyme during a single turnover. We, however, discovered that the amount of intermediate formed on the enzyme was below the detection level of the experiment (McQueney, 1991). Thus, a different strategy, which involved the use of an alternate substrate (oxalyl phosphate) that would form a stable reaction intermediate (oxalate instead of the pyruvyl enolate), was used in the single turnover experiment. Oxalyl phosphate has been shown to substitute for PEP as substrate for pyruvate kinase, pyruvate phosphate dikinase (PPDK), and PEP carboxykinase (Kofron \& Reed, 1990). In the case of PPDK, catalysis proceeds via a phosphoenzyme-pyruvyl enol(ate) intermediate. Reaction of oxalyl phosphate with PPDK/Mg(II) produces a stable, tightly associated phosphoenzyme-

\footnotetext{
${ }^{2}$ The $K_{\mathrm{d}}$ values are derived from the inhibition constants of oxalate and PEP vs P-pyr (Seidel \& Knowles, 1994).
} 
oxalate-Mg(II) complex (Kofron et al., 1988; Kofron \& Reed, 1990). On the basis of this observation, our expectation was that if the PEP mutase catalysis proceeds via the phosphoenzyme mechanism, the enzyme would catalyze the phosphorylation of it own active site nucleophile with the oxalyl phosphate and the resulting complex of oxalate and phosphoryl enzyme [plus its $\mathrm{Mg}$ (II) cofactor] would be stable and readily isolated. On the other hand, if the mutase reaction of oxalyl phosphate follows a dissociative pathway, oxalate and metaphosphate, captured as orthophosphate, would be formed. In the text which follows the results from the single turnover reaction of $\left[{ }^{32} \mathrm{P}\right]$ oxalyl phosphate with PEP mutase are presented along with those obtained with PPDK.

\section{MATERIALS AND METHODS}

General. P-pyr was prepared from P-Ala by the method of Anderson et al. (1984) or by the method of Sparkes et al. (1990). Reactants (PEP, P-Ala, and AEP), enzymes [malate dehydrogenase (Thermus flavua), lactate dehydrogenase (type XI from rabbit muscle), pyruvate kinase (type III from porcine heart), L-aspartate aminotransferase (type II-A from porcine heart), and alcohol dehydrogenase (Bakers yeast)], cofactors (TPP, PLP), Dowex resins, and protease inhibitors were purchased from Sigma Chemical Co. Protein concentration determination kits based on Bradford's method (Bradford, 1976) were from Bio-Rad. T. pyriformis (w) was obtained from the American Type Culture Collection (ATCC No. 151905). $\quad\left[{ }^{32} \mathrm{P}\right] \mathrm{H}_{3} \mathrm{PO}_{4}(27930 \mathrm{Ci} / \mathrm{mmol}, 10 \mathrm{mCi}$ in 20 $\mathrm{mL}$ of $\left.\mathrm{H}_{2} \mathrm{O}\right)$ was from ICN. $\left[{ }^{14} \mathrm{C}\right]$ oxalic acid $(50 \mathrm{mCi} / \mathrm{mmol})$ was from NEN. ${ }^{31} \mathrm{P}-\mathrm{NMR}$ spectra $\left(\mathrm{D}_{2} \mathrm{O}\right.$ solvent, $\mathrm{pH} 8,25$ ${ }^{\circ} \mathrm{C}$ ) were recorded on Bruker WP-200 and AM-400 instruments at operating frequencies of 81 and $162 \mathrm{MHz}$. The chemical shifts are reported in parts per million relative to $85 \%(d 0.0)$ phosphoric acid as an external standard.

Enzyme Purifications. PPDK: Clostridium symbiosum PPDK was purified from the Escherichia coli clone (Pocalyko, 1990) to a specific activity of 23 units/mg according to the method described in Mehl et al. (1994). Phosphonatase: Bacillus cereus phosphonatase was purified using the general method reported in LaNauze et al. (1977) modified as described in Olsen et al. (1988). PEP Mutase: T. pyriformis PEP mutase was purified using a procedure adapted from that reported by Bowman et al. (1990). Tetrahymena cells (250 g from $21 \mathrm{~L}$ of culture) were suspended in $500 \mathrm{~mL}$ of $\mathrm{pH} 7.5$ buffer $\left(50 \mathrm{mM} \mathrm{K}^{+}\right.$Hepes, 5 mM DTT, $1 \mathrm{mM}$ EDTA, $1 \mathrm{mM}$ benzamidine hydrochloride, $50 \mu \mathrm{g} / \mathrm{mL}$ trypsin inhibitor, $1 \mathrm{mM}$ 1,10-phenanthroline, and $50 \mu \mathrm{M}$ PMSF) and lysed by freezing $\left(-80{ }^{\circ} \mathrm{C}\right)$, thawing $(4$ ${ }^{\circ} \mathrm{C}$ ), and blending the suspension in a Waring blender. The homogenate was centrifuged at $17000 \mathrm{~g}$, streptomycin sulfate $(1.5 \% \mathrm{w} / \mathrm{v})$ was added to the supernatant, and the centrifugation step was repeated. Solid ammonium sulfate (45\%) was added with stirring to the supernatant, and the resulting mixture was centrifuged. The mutase was then precipitated at $70 \%$ ammonium sulfate, pelleted by centrifugation (6 g of crude protein), and then dissolved in $\mathrm{pH} 7.5$ buffer $(50$ $\mathrm{mM}$ triethanolamine, $0.5 \mathrm{mM}$ DTT, and $5 \mathrm{mM} \mathrm{MgCl}_{2}$ ) containing $25 \%(\mathrm{w} / \mathrm{v})$ ammonium sulfate. After this solution was loaded onto a $90 \times 3.5 \mathrm{~cm}$ phenyl-Sepharose CL-4B column (equilibrated with the same buffer/ammonium sulfate solution), the protein was eluted with a $1.5 \mathrm{~L}$ linear gradient of $25-0 \%$ ammonium sulfate in buffer and then with $1 \mathrm{~L}$ of buffer. The mutase-containing fractions (eluted with buffer) were then combined and chromatographed on a 40 $\times 5 \mathrm{~cm}$ DEAE-cellulose column. The mutase was eluted with buffer and then loaded onto a $35 \times 3.5 \mathrm{~cm}$ hydroxyapatite column. The column was eluted with a $1.5 \mathrm{~L}$ linear gradient of $0-1 \mathrm{M}$ potassium phosphate in buffer. The mutase active fractions were combined, made $25 \%$ in ammonium sulfate, and then loaded onto a $1 \times 10 \mathrm{~cm}$ phenyl-Sepharose CL-4B column. The mutase was eluted from the column with buffer, divided into $1 \mathrm{~mL}$ samples, and stored at $-80{ }^{\circ} \mathrm{C}$ : yield $7.6 \mathrm{mg}, 790$ units, specific activity $=104$ units $/ \mathrm{mg}$ of protein. The enzyme was analyzed by using SDS-PAGE chromatography and judged to be pure. P-pyr decarboxylase from $T$. pyriformis was partially purified using the following procedure. Frozen Tetrahymena cells $\left(292 \mathrm{~g},-80^{\circ} \mathrm{C}\right)$ were defrosted in $1.4 \mathrm{~L}$ of a solution of $0.2 \mathrm{M}$ sucrose, $5 \mathrm{mM}$ EDTA, $5 \mathrm{mM}$ DTT,

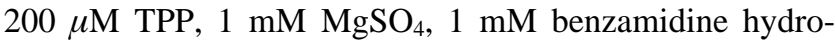
chloride, and $50 \mu \mathrm{g} / \mathrm{mL}$ trypsin inhibitor at $\mathrm{pH} 7.3$ with gentle stirring. The resulting solution was passed through a tissue homogenizer and then centrifuged at $17000 \mathrm{~g}$. The pellet ( $\mathrm{ca}$. $100 \mathrm{~g}$ of crude membrane) was suspended in $550 \mathrm{~mL}$ of 0.2 $\mathrm{M}$ potassium phosphate in $50 \mathrm{mM} \mathrm{K}{ }^{+}$Mes, $5 \mathrm{mM}$ DTT, 1 $\mathrm{mM}$ EDTA, $1 \mathrm{mM}$ benzamidine hydrochloride, $50 \mu \mathrm{g} / \mathrm{mL}$ trypsin inhibitor, $200 \mu \mathrm{M}$ TPP, $1 \mathrm{mM} \mathrm{MgSO}_{4}$, and $10 \%$ glycerol (v/v) at $\mathrm{pH}$ 6.0. After being stirred for $1 \mathrm{~h}$ at $4{ }^{\circ} \mathrm{C}$, the suspension was centrifuged. Streptomycin sulfate $(1.5 \%$ $\mathrm{w} / \mathrm{v}$ ) was added to the supernatant followed by centrifugation. The crude protein fraction $(1.5 \mathrm{~g})$, precipitated from the supernatant by $40-75 \%$ ammonium sulfate and pelleted by centrifugation, was dissolved in buffer $\left(50 \mathrm{mM} \mathrm{K}^{+} \mathrm{Mes}, 200\right.$ $\mu \mathrm{M}$ TPP, and 0.5 mM DTT, pH 6.0) and loaded onto a 5.5 $\times 30 \mathrm{~cm}$ hydroxyapatite column equilibrated in the same buffer. The column was eluted with $100 \mathrm{~mL}$ of buffer, followed by $700 \mathrm{~mL}$ of $0.35 \mathrm{M}$ potassium phosphate in buffer, and finally with a $2 \mathrm{~L}$ linear gradient of $0.35-0.80$ $\mathrm{M}$ potassium phosphate in buffer. The decarboxylase, which eluted at $0.5 \mathrm{M}$ phosphate, was precipitated with $75 \%$ ammonium sulfate and then isolated by centrifugation to yield $52 \mathrm{mg}$ of crude enzyme (4.3 units) having a specific activity $=0.08$ unit $/ \mathrm{mg}$ of protein.

Spectrophotometric Enzyme Activity Assays. All assays were performed at $25^{\circ} \mathrm{C}$. The oxidation of NADH was monitored at $340 \mathrm{~nm}\left(\Delta \epsilon=6220 \mathrm{M}^{-1} \mathrm{~cm}^{-1}\right)$ for each of the coupled assays described below. The PEP mutase activity was determined by monitoring the formation of PEP from P-pyr by using a coupled assay with PK and LDH (Bowman et al., 1990). The rate of PEP formation from $\mathrm{P}$-pyr was determined with a $1 \mathrm{~mL}$ assay solution containing $50 \mathrm{mM} \mathrm{K}{ }^{+}$Hepes (pH 7.5), 1 mM P-pyr, 5 mM ADP, 6 mM $\mathrm{MgCl}_{2}, 0.2 \mathrm{mM} \mathrm{NADH}, 10$ units of PK, and 10 units of LDH. When oxalate was present, the PEP mutase activity was determined by using a direct spectrophotometric assay wherein the $A_{233 \mathrm{~nm}}\left(\Delta \epsilon=1500 \mathrm{M}^{-1} \mathrm{~cm}^{-1}\right.$ at $\left.\mathrm{pH} 7.5\right)$ resulting from the conversion of P-pyr to PEP in a $1 \mathrm{~mL}$ assay solution containing $50 \mathrm{mM}$ Tris $\cdot \mathrm{HCl}(\mathrm{pH} 7.5)$ and $5 \mathrm{mM} \mathrm{MgCl}_{2}$ was monitored. P-pyr decarboxylase activity was measured by using a coupled assay (for $\mathrm{P}$-ald) consisting of phosphonatase and ADH. The $1 \mathrm{~mL}$ assay mixture contained $50 \mathrm{mM} \mathrm{K}^{+}$Mes, $25 \mathrm{mM}$ oxalate (to inhibit PEP mutase), $1 \mathrm{mM}$ P-pyr, $1.25 \mathrm{mM}$ TPP, $5 \mathrm{mM} \mathrm{MgCl} 2,0.2 \mathrm{mM}$ NADH, 0.02 unit of phosphonatase, and 10 units of $\mathrm{ADH}$. Alternately, the amount of P-ald produced from P-pyr in a $0.5 \mathrm{~mL}$ incubation 
solution containing $50 \mathrm{mM} \mathrm{K}{ }^{+} \mathrm{Mes}$ (pH 6.0), 4 mM P-pyr,

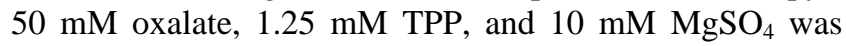
determined after incubation of the solution at room temperature for $2-10 \mathrm{~h}$. An aliquot $(50-200 \mu \mathrm{L})$ was taken and added to a $1 \mathrm{~mL}$ assay solution containing $50 \mathrm{mM} \mathrm{K}^{+}$Hepes (pH 7.5), $5 \mathrm{mM} \mathrm{MgCl}, 0.2 \mathrm{mM} \mathrm{NADH}, 0.01$ unit of phosphonatase, and 10 units of ADH. Control reactions lacking either P-pyr or phosphonatase were carried out to check for background activity. Malate dehydrogenase activity was determined using $1 \mathrm{~mL}$ reaction solutions containing $5 \mathrm{mM} \mathrm{MgCl} 2,0.2 \mathrm{mM} \mathrm{NADH}$, and varying concentrations of malate or P-pyr in $50 \mathrm{mM} \mathrm{K}{ }^{+}$Hepes or $50 \mathrm{mM} \mathrm{K}{ }^{+}$Mes (pH 6.0-7.5) at $25^{\circ} \mathrm{C}$. Aspartate transaminase activity was determined by using the substrates $\alpha$-ketoglutarate (or P-pyr) and L-Asp and measuring the rate of formation of oxaloacetate from the L-Asp by using the MDH-NADH spectrophotometric assay. The $1 \mathrm{~mL}$ assay solutions contained (in addition to the transaminase) varying concentrations of $\alpha$-ketoglutarate (or P-pyr), $25 \mathrm{mM}$ PLP, $5 \mathrm{mM} \mathrm{MgCl}_{2}, 0.2$ $\mathrm{mM}$ NADH, $20 \mathrm{mM} \mathrm{L}-\mathrm{Asp}$, and 10 units of MDH in 50 $\mathrm{mM} \mathrm{K}{ }^{+}$Hepes $\left(\mathrm{pH} \mathrm{7.5)}\right.$ at $25^{\circ} \mathrm{C}$. Control reactions lacking either P-pyr or L-Asp were carried out to determine the background activity.

${ }^{31}$ P-NMR and Kinetic Analysis of Product Formation in the Malate Dehydrogenase and Aspartate Transaminase Catalyzed Reaction of P-pyr. ${ }^{31} P$-NMR: Twenty units of PEP mutase was mixed with 400 units of malate dehydrogenase in $1 \mathrm{~mL}$ of $50 \% \mathrm{D}_{2} \mathrm{O}$ solution $(\mathrm{pH} 6.0)$ containing $25 \mathrm{mM} \mathrm{K}^{+}$Mes, $50 \mathrm{mM}$ PEP, $5 \mathrm{mM} \mathrm{MgCl}_{2}$, and $400 \mathrm{mM}$ NADH. The ${ }^{31} \mathrm{P}-\mathrm{NMR}$ spectrum of the solution was measured after a $24 \mathrm{~h}$ incubation period at $25^{\circ} \mathrm{C}$. Thirty units of PEP mutase was mixed with 2000 units of Asp transaminase in a $25 \mathrm{~mL}$ solution $(\mathrm{pH} 7.5)$ containing 50 $\mathrm{mM} \mathrm{K}{ }^{+}$Hepes, $25 \mathrm{mM}$ PEP, $130 \mathrm{mM} \mathrm{L}-G l u$, and $6.5 \mathrm{mM}$ PLP at $25^{\circ} \mathrm{C}$. Five milliliter aliquots of the reaction solution were taken at 1,2 , and 4 days and quenched by the addition of $100 \mu \mathrm{L}$ of $10 \mathrm{M}$ perchloric acid. Following the addition of 3-phosphonopropionate (to serve as an internal standard) the solution was centrifuged, and the resulting supernatant was neutralized with $10 \mathrm{M} \mathrm{KOH}$. The $\mathrm{KClO}_{4}$ precipitant formed was removed by centrifugation. The supernatant was dried in vacuo. The residue was dissolved in $\mathrm{D}_{2} \mathrm{O}$, the solution $\mathrm{pH}$ was adjusted to 8 (meter reading) with $10 \mathrm{M}$ $\mathrm{KOH}$, and the resulting sample was analyzed by ${ }^{31} \mathrm{P}-\mathrm{NMR}$. Kinetic Analysis: Initial velocity studies were carried out to determine the kinetic constants $\left(k_{\text {cat }}\right.$ and $\left.K_{\mathrm{m}}\right)$ for $\mathrm{MDH}-$ catalyzed reduction of P-pyr with NADH and for Asp transaminase-catalyzed transamination of P-pyr with aspartate. The inhibition constant $\left(K_{\mathrm{i}}\right)$ of PEP as a competitive inhibitor vs P-pyr was also determined. Accordingly, the initial reaction velocities were measured as a function of P-pyr concentration $(0.5-20 \mathrm{mM}$ for malate dehydrogenase and $0.3-5.0 \mathrm{mM}$ for Asp transaminase) in the presence and absence of PEP $(1-10 \mathrm{mM})$ by using the conditions given for the spectrophotometric assays described above. The initial velocity data were analyzed by computer fitting the data to eqs 1 and 2 using the HYPERL and COMPL Fortran programs of Cleland (1979).

$$
V_{0}=V_{\max }[\mathrm{S}] /\left([\mathrm{S}]+K_{\mathrm{m}}\right)
$$

$$
V_{0}=V_{\max }[\mathrm{S}] /\left[K_{\mathrm{m}}\left(1+[\mathrm{I}] / K_{\mathrm{i}}\right)+[\mathrm{S}]\right]
$$

In the equations, $V_{0}=$ initial velocity, $V_{\max }=$ maximal velocity, $[\mathrm{S}]=$ substrate concentration, $[\mathrm{I}]=$ inhibitor concentration, $K_{\mathrm{m}}=$ the Michaelis constant, and $K_{\mathrm{i}}=$ the inhibition constant.

Determination of the Kinetic Constants of the T. pyriformis PEP Mutase and P-pyr Decarboxylase. PEP mutase: The $K_{\mathrm{m}}$ and $k_{\text {cat }}$ of PEP mutase in the PEP $\rightarrow$ P-pyr direction were determined from the initial velocities measured as a function of PEP concentration $(1-10 \mathrm{mM})$. The $1 \mathrm{~mL}$ reaction solutions contained $50 \mathrm{mM} \mathrm{K}{ }^{+}$Hepes ( $\mathrm{pH} 7.5$ ), 0.2 mM NADH, 0.02 unit of phosphonatase, 5 units of ADH, 0.002 unit of P-pyr decarboxylase, $1.25 \mathrm{mM}$ TPP, and $5 \mathrm{mM}$ $\mathrm{MgCl}_{2}$ at $25^{\circ} \mathrm{C}$. The reaction was initiated by the addition of PEP mutase. The initial velocity data were analyzed using eqs 1 and 2 as previously described. The $K_{\text {eq }}$ for the reaction was determined by measuring the amount of P-pyr formed from PEP in solutions equilibrated with PEP mutase. Specifically, PEP mutase (0.07 unit; PEP to P-pyr activity) was incubated in solutions containing $50 \mathrm{mM} \mathrm{K}^{+}$Hepes $(\mathrm{pH}$ 7.5), $5 \mathrm{mM} \mathrm{MgCl}_{2}$, and varying PEP concentrations (10, 30 and $50 \mathrm{mM}$ ) for $3 \mathrm{~h}$ at $25^{\circ} \mathrm{C}$ (loss of PEP by hydrolysis under these conditions is negligible). The reaction was quenched with $20 \mu \mathrm{L}$ of perchloric acid, and the denatured protein was removed by using a microcentrifuge. The resulting solution was neutralized with $10 \mathrm{M} \mathrm{KOH}$ and incubated with 0.003 unit of P-pyr decarboxylase in the presence of $1.25 \mathrm{mM}$ TPP and $100 \mathrm{mM}$ oxalate (to inhibit any residual PEP mutase activity possibly present) for $8 \mathrm{~h}$ at $25^{\circ} \mathrm{C}$. The P-ald produced was then assayed by adding a $50-200 \mu \mathrm{L}$ aliquot to a $1 \mathrm{~mL}$ reaction solution containing $5 \mathrm{mM} \mathrm{MgCl}_{2}, 0.2 \mathrm{mM} \mathrm{NADH}, 0.01$ unit of phosphonatase, and 10 units of $\mathrm{ADH}$ in $50 \mathrm{mM} \mathrm{K}{ }^{+}$Hepes $(\mathrm{pH} \mathrm{7.5)}$ and measuring the decrease in solution absorbance at $340 \mathrm{~nm}$. The control reactions which did not contain PEP mutase were performed under the same conditions. The $K_{\text {eq }}$ was calculated from the ratio of the concentrations of P-pyr and PEP (remaining) present in the PEP mutase solutions at equilibrium. P-pyr decarboxylase: The $K_{\mathrm{m}}$ for P-pyr was determined by measuring the initial velocity of P-ald formation as a function of P-pyr concentration $(4-100 \mu \mathrm{M})$. Reactions contained $200 \mu \mathrm{M}$ TPP, $2 \mathrm{mM} \mathrm{MgSO}_{4}, 200 \mu \mathrm{M}$ NADH, 10 units of alcohol dehydrogenase, and 0.1 unit of phosphonatase in $1 \mathrm{~mL}$ of $50 \mathrm{mM} \mathrm{K}{ }^{+}$Hepes buffer $\left(\mathrm{pH} 7.5,25^{\circ} \mathrm{C}\right)$ and were initiated by the addition of P-pyr decarboxylase.

Synthesis and Purification of $\left.{ }^{32} \mathrm{P}\right] \mathrm{Oxalyl}$ Phosphate. Oxalyl phosphate was synthesized and purified as described by Kofron and Reed (1990). The oxalyl phosphate samples were assayed by measuring the absorbance at $215 \mathrm{~nm}$ and by measuring the ${ }^{31} \mathrm{P}-\mathrm{NMR}$ spectrum. $\left[{ }^{32} \mathrm{P}\right] \mathrm{Oxalyl}$ phosphate was synthesized and purified on one-tenth the scale $(1 \mathrm{~mL})$ using a modified method. All synthetic procedures were performed in a fume hood, and all purification work was carried out in a cold box $\left(10^{\circ} \mathrm{C}\right)$. Ten microliters of oxalyl chloride (final concentration $1.1 \mathrm{M}$ ) was added to a mixture of $50 \mathrm{~mL}$ of $2 \mathrm{M} \mathrm{K}_{2} \mathrm{H}^{32} \mathrm{PO}_{4}$ cooled in an ice bath. After 5 $\min$, the $\mathrm{pH}$ of the solution was adjusted to $4-5$ with $3 \mathrm{~mL}$ of ice-cold dilute $\mathrm{KOH}$, and the final volume was adjusted to $5 \mathrm{~mL}$ with ice-cold distilled water. The resulting solution was applied to a $2 \mathrm{~mL}$ column of AG1-X8 200-400 mesh $\left(\mathrm{Cl}^{-}\right.$form $)$which had been equilibrated with cold $\left(0{ }^{\circ} \mathrm{C}\right)$ deionized water. The column was eluted with $15 \mathrm{~mL}$ of 0.05 
$\mathrm{M} \mathrm{MgCl}_{2}$, then with $10 \mathrm{~mL}$ of cold water, and finally with $80 \mathrm{~mL}$ of a $0.1-1 \mathrm{M} \mathrm{KCl}$ linear gradient in $0{ }^{\circ} \mathrm{C}$ water (at a flow rate of $0.25 \mathrm{~mL} / \mathrm{min}$ with a fraction volume of $1 \mathrm{~mL}$ ). The radioactivity of the column eluant was monitored using a Geiger counter connected to the exit tubing of the column. The unreacted inorganic phosphate eluted with the $0.05 \mathrm{M}$ $\mathrm{MgCl}_{2}$. Five microliter aliquots of $\mathrm{KCl}$ gradient fractions were counted in $5 \mathrm{~mL}$ of liquid scintillation cocktail. The radioactive oxalyl phosphate $(100 \mathrm{mCi} / \mathrm{mmol})$ eluting at approximately $20 \mathrm{~mL}(0.3 \mathrm{M} \mathrm{KCl})$ of the $80 \mathrm{~mL} 0.1-1.0 \mathrm{M}$ $\mathrm{KCl}$ gradient was dispensed into $100 \mu \mathrm{L}$ aliquots, frozen, and stored at $-80{ }^{\circ} \mathrm{C}$.

Oxalate and Oxalyl Phosphate Inhibition of PEP Mutase. The inhibition constants of oxalate and oxalyl phosphate as competitive inhibitors vs P-pyr were determined in $50 \mathrm{mM}$ Tris buffer ( $\mathrm{pH} 7.5$ ) containing $5 \mathrm{mM} \mathrm{MgCl}_{2}$ at fixed P-pyr concentration $(200 \mu \mathrm{M})$ and varying oxalate and oxalyl phosphate concentrations $(0-500 \mu \mathrm{M})$. PEP mutase activity was measured by using a direct spectrophotometric assay (described above) wherein the increase in the $A_{233 \mathrm{~nm}}$ of the reaction solution resulting from the conversion of P-pyr to PEP was monitored. The $K_{\mathrm{i}}$ was determined from the initial velocity data using eq 2 as described previously.

Phosphoenzyme (E-P) Formation from the Reaction of PPDK with [ ${ }^{32}$ P]Oxalyl Phosphate. E-P formation was tested by the reaction of $20 \mu \mathrm{M}$ PPDK with $200 \mu \mathrm{M}\left[{ }^{32} \mathrm{P}\right]-$ oxalyl phosphate $(82.4 \mathrm{mCi} / \mathrm{mmol}$; synthesized and purified as described previously) in a $80 \mu \mathrm{L}$ solution $\left(25^{\circ} \mathrm{C}\right)$ containing $0.44 \mathrm{mM} \mathrm{MnCl} 2$ (or $\mathrm{MgCl}_{2}$ ), $75 \mathrm{mM} \mathrm{NH}_{4} \mathrm{Cl}$, and $20 \mathrm{mM} \mathrm{K}^{+}$Hepes ( $\mathrm{pH}$ 6.8). The reaction solutions were quenched at varying conversions with $160 \mu \mathrm{L}$ of $0.6 \mathrm{~N} \mathrm{HCl}$ and $100 \mu \mathrm{L}$ of $\mathrm{CCl}_{4}(15 \mathrm{~s}$ to $120 \mathrm{~min}$ reaction period for the $\mathrm{MnCl}_{2}$-activated enzyme and 5 to $240 \mathrm{~min}$ for the $\mathrm{MgCl}_{2}-$ activated enzyme). The resulting solution was vigorously vortexed, and the denatured enzyme was pelleted by microcentrifugation for $2 \mathrm{~min}$. The pellet was removed from the solution using a glass micropipet and rolled onto tissue to remove solvent. The pelleting procedure (add $\mathrm{HCl} / \mathrm{CCl}_{4}$, vortex, centrifuge, and roll pellet onto the tissue) was performed twice on the reaction mixture. The combined enzyme pellet was boiled in $500 \mu \mathrm{L}$ of $10 \mathrm{~N} \mathrm{H}_{2} \mathrm{SO}_{4}$ for 4 min. The radioactivity of the resulting pellet solution and the supernatant of the reaction solution were measured by using a scintillation counter.

Test of PEP Mutase Phosphoenzyme (E-P) Formation with $\left.{ }^{32} P\right] O x a l y l$ Phosphate. E-P formation was tested by the reaction of $20 \mu \mathrm{M}$ PEP mutase with $200 \mu \mathrm{M}\left[{ }^{32} \mathrm{P}\right]$ oxalyl phosphate $(42.4 \mathrm{mCi} / \mathrm{mmol})$ in an $80 \mathrm{~mL}$ solution containing $1 \mathrm{mM} \mathrm{MnCl} 2$ (or $\mathrm{MgCl}_{2}$ ) and $20 \mathrm{mM} \mathrm{K}{ }^{+}$Hepes ( $\mathrm{pH}$ 7.0) for varying times (2 and $30 \mathrm{~min}$ for $\mathrm{MnCl}_{2}$ and $10 \mathrm{~min}$ for $\left.\mathrm{MgCl}_{2}\right)$ at $25^{\circ} \mathrm{C}$. The same reaction was performed at $\mathrm{pH}$ 6.0 (20 $\mathrm{mM} \mathrm{K}^{+}$Mes) and pH $7.6\left(20 \mathrm{mM} \mathrm{K}{ }^{+}\right.$Hepes $)$with 1 $\mathrm{mM} \mathrm{MnCl}$. Analysis of the reaction solution for $\left.{ }^{32} \mathrm{P}\right] \mathrm{E}-\mathrm{P}$ was carried out in the same manner as previously described for the PPDK E-P formation. PEP mutase [ $\left.{ }^{32} \mathrm{P}\right] \mathrm{E}-\mathrm{P}$ formation was also examined using G-25 column chromatography to separate the enzyme from the reaction mixture. Accordingly, an $80 \mu \mathrm{L}$ reaction solution of $20 \mu \mathrm{M}$ PEP mutase with $200 \mu \mathrm{M}\left[{ }^{32} \mathrm{P}\right]$ oxalyl phosphate $(40 \mathrm{mCi} / \mathrm{mmol}), 2 \mathrm{mM} \mathrm{MnCl}_{2}$, and $20 \mathrm{mM} \mathrm{K}{ }^{+}$Hepes (pH 7.0) was incubated for 10 or 60 min at $25^{\circ} \mathrm{C}$ and then loaded onto a Sephadex G-25 column $(1.3 \mathrm{~cm} \times 60 \mathrm{~cm})$ which had been equilibrated with $20 \mathrm{mM}$ $\mathrm{K}^{+}$Hepes (pH 7.0) containing 0.2 M KCl. The column was eluted with the equilibration buffer at a flow rate $0.15 \mathrm{~mL} /$ min. The radioactivity and the enzyme activity contained in each $1 \mathrm{~mL}$ fraction were measured by scintillation counting and by using the (pyruvate kinase/LDH/NADH) coupled spectrophotometric assay as described previously.

\section{RESULTS AND DISCUSSION}

Kinetics and Thermodynamics of PEP Mutase Catalyzed $P$-pyr Formation and Coupling. Measurement of the kinetic constants of the PEP mutase reaction catalyzed in the P-pyrforming (physiological) direction required the development of an efficient coupling reaction. Three coupling systems, each of which served as the basis for a spectrophotometric continuous assay, were evaluated. These are the malate dehydrogenase-NADH system, the aspartate-glutamate/ malate dehydrogenase-NADH system, and the phosphonopyruvate decarboxylase/phosphonoacetaldehyde hydrolase/ alcohol dehydrogenase-NADH system. With the exception of P-pyr decarboxylase and phosphonoacetaldehyde hydrolase (phosphonatase) the enzymes used in these coupling systems are commercially available.

Seto and co-workers had reported (Seto et al., 1991), on the basis of reactions analyzed by thin-layer chromatography, that P-pyr formed from PEP by PEP mutase can be trapped in situ by reduction with $\mathrm{NADH} /$ malate dehydrogenase. We further examined this coupling reaction using ${ }^{31} \mathrm{P}-\mathrm{NMR}$ techniques to identify products and initial velocity techniques to evaluate coupling efficiency. ${ }^{31} \mathrm{P}-\mathrm{NMR}$ analysis of a 1 $\mathrm{mL}$ reaction mixture initially containing 400 units of malate dehydrogenase, $50 \mathrm{mM} \mathrm{P-pyr,} 80 \mathrm{mM} \mathrm{NADH}, 5 \mathrm{mM} \mathrm{MgCl}$, and $20 \mathrm{mM} \mathrm{K}^{+} \mathrm{Mes}\left(\mathrm{pH} 6.0,25^{\circ} \mathrm{C}\right)$ revealed that within a $24 \mathrm{~h}$ incubation period $c a .40 \%$ of the P-pyr $(\delta=+11.3$ $\mathrm{ppm}$ at $\mathrm{pH} 6.0)$ had been converted to phosphonolactate $(\delta$ $=+20.8 \mathrm{ppm}$ at $\mathrm{pH} 6.0$ ). The efficiency of the malate dehydrogenase catalyzed reduction of P-pyr with NADH was then examined by measuring the $K_{\mathrm{m}}$ and $k_{\mathrm{cat}}$ for the enzymesubstrate pair. The maximal activity of malate dehydrogenase with oxaloacetate as substrate vs that with P-pyr as substrate was found to be 17 vs 0.03 unit $/ \mathrm{mg}$ at $\mathrm{pH} 7.5,12$ vs 0.04 unit $/ \mathrm{mg}$ at $\mathrm{pH} 6.5$, and $11 \mathrm{vs} 0.11 \mathrm{unit} / \mathrm{mg}$ at $\mathrm{pH}$ 6.0. At pH 6 the $K_{\mathrm{m}}$ for P-pyr $=2.6 \pm 1.6 \mathrm{mM}$ and the $K_{\mathrm{i}}$ for PEP as a competitive inhibitor vs P-pyr $=1.6 \pm 0.3$ $\mathrm{mM}$. These kinetic constants were then used, along with eq 2, to evaluate the efficiency of the malate dehydrogenase as a couple to the PEP mutase reaction. A typical PEP mutase reaction may start with $10 \mathrm{mM}$ PEP to generate $c a$. $0.01 \mathrm{mM}$ P-pyr at equilibrium. Under these conditions the efficiency of the malate dehydrogenase catalyzed reduction of P-pyr would drop (as calculated using eq 2) to $1 \times 10^{-4}$ unit/mg, well outside a practical range for initial velocity measurements of PEP mutase catalysis to be made.

The aspartate transaminase coupling system was tested next. This coupling system is based on the utilization of P-pyr as the acceptor of the ammonium group transferred from L-aspartate (or L-glutamate). The formation of phosphonoalanine from the reaction of $25 \mathrm{mM}$ PEP, $130 \mathrm{mM}$ L-glutamate, $6.5 \mathrm{mM}$ pyridoxal phosphate, $5 \mathrm{mM} \mathrm{MgCl}$, 30 units $/ \mathrm{mL}$ PEP mutase, and 2000 units $/ \mathrm{mL}$ aspartate transaminase in $50 \mathrm{mM} \mathrm{K}{ }^{+}$Hepes $\left(\mathrm{pH} 7.5,25{ }^{\circ} \mathrm{C}\right)$ was monitored by ${ }^{31} \mathrm{P}-\mathrm{NMR}$. After 4 days of incubation all of the PEP $(\delta-0.3 \mathrm{ppm})$ had been converted to phosphonoalanine $(\delta+17.8 \mathrm{ppm})$. By using the malate dehydrogenase 
catalyzed reduction of $\alpha$-ketoglutarate with NADH to couple to the transaminase reaction, the steady-state kinetic parameters of the P-pyr/aspartate transaminase reaction were measured. The $K_{\mathrm{m}}$ for P-pyr was determined to be $2.5 \pm$ $0.2 \mathrm{mM}$ and the specific activity to be $25 \mathrm{units} / \mathrm{mg}$ (with $\alpha$-ketoglutarate under these reaction conditions the specific activity is 250 units/mg). The inhibition constant for PEP functioning as a competitive inhibitor of the aspartate transaminase vs P-pyr was measured at $3.3 \pm 0.2 \mathrm{mM}$. Thus, assuming that the equilibrium constant for the PEP mutase reaction is $c a .1 \times 10^{-3}$, the specific activity of the aspartate transaminase toward P-pyr formed in the presence of $10 \mathrm{mM}$ $\mathrm{PEP}$ is estimated (eq 2) at $2 \times 10^{-2} \mathrm{unit} / \mathrm{mg}$. Although this coupling system is considerably superior to the malate dehydrogenase system, it is still not as efficient as we would like.

Finally, we turned to P-pyr decarboxylase (partially purified from $T$. pyriformis to specific activity $=0.1$ unit/ $\mathrm{mg}$ ) to serve as the coupling enzyme. Since catalysis by this enzyme is coupled to that of PEP mutase in the AEP pathway (Barry et al., 1988), a high $V_{\mathrm{m}} / K_{\mathrm{m}}$ was anticipated. Indeed, the $K_{\mathrm{m}}$ determined for P-pyr as substrate for the decarboxylase is $4 \pm 0.3 \mu \mathrm{M}$ at $\mathrm{pH} 7.5$ and $15 \pm 2 \mu \mathrm{M}$ at $\mathrm{pH}$ 6.0. No inhibition of the enzyme was observed in the presence of $5 \mathrm{mM}$ PEP. The phosphonoacetaldehyde (Pald) formation was monitored spectrophotometrically using the coupling enzymes phosphonatase (purified from $B$. cereus) and alcohol dehydrogenase. Accordingly, the values of $K_{\mathrm{m}}=770 \pm 50 \mu \mathrm{M}$ and $k_{\text {cat }}=5 \mathrm{~s}^{-1}$ for P-pyr formation

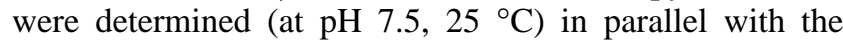
determination of the $K_{\mathrm{m}}=3.5 \pm 0.1 \mu \mathrm{M}$ and $k_{\mathrm{cat}}=100 \mathrm{~s}^{-1}$ values for the reverse reaction (monitored using the PK/LDH coupling system). The $k_{\mathrm{cat}} / K_{\mathrm{m}}$ values for the P-pyr-forming (forward) and PEP-forming (reverse) direction $\left(6 \times 10^{3} \mathrm{M}^{-1}\right.$ $\mathrm{s}^{-1}$ and $3 \times 10^{7} \mathrm{M}^{-1} \mathrm{~s}^{-1}$, respectively) were used to calculate the $K_{\text {eq }}$ from the Haldane equation: $K_{\text {eq }}=\left(k_{\text {cat }} / K_{\mathrm{m}}\right)_{\mathrm{f}} /\left(k_{\text {cat }} /\right.$ $\left.K_{\mathrm{m}}\right)_{\mathrm{r}}=2 \times 10^{-4}$. The $K_{\text {eq }}$ was also determined by measuring the amount of P-pyr formed from PEP $(10,30$, and $50 \mathrm{mM})$ in solutions equilibrated with PEP mutase and $5 \mathrm{mM} \mathrm{MgCl}$ ( $\mathrm{pH} 7.5)$. The $K_{\mathrm{eq}}$ values measured for these reactions are 9 $\times 10^{-4}, 7 \times 10^{-4}$, and $8 \times 10^{-4}$, respectively.

Energetics of $\mathrm{P}-\mathrm{C}$ Bond Formation. The equilibrium constant for the mutase reaction determined in this study $\left(2-9 \times 10^{-4}\right)$ is in good agreement with the theoretical value of $4 \times 10^{-4}$ computed from crystal structure data (Schwalbe \& Freeman, 1990). Nature's use of the high-energy vinyl phosphate ester bond in PEP to serve as the precursor to the $\mathrm{P}-\mathrm{C}$ bond in $\mathrm{P}$-pyr only partially offsets the difference in the intrinsic energies of the $\mathrm{P}-\mathrm{O}$ vs $\mathrm{P}-\mathrm{C}$ bonds. It is a well-known fact that enzymes use intrinsic binding energy to minimize the energy difference between bound reactant and product states for the sake of catalytic efficiency (Albery $\&$ Knowles, 1976). Thus, we predict that the $K_{\text {eq }}$ value for the internal equilibrium, $[\mathrm{E} \cdot \mathrm{P}-\mathrm{pyr}] /[\mathrm{E} \cdot \mathrm{PEP}]$ (to be determined in future studies), is significantly closer to unity than is the $K_{\text {eq }}$ value for the external equilibrium, [P-pyr]/[PEP].

In vivo, the unfavorable external equilibrium of the PEP mutase reaction is expected to be driven forward by the next step in the AEP biosynthetic pathway, which is a thermodynamically favorable decarboxylation reaction catalyzed by P-pyr decarboxylase (Scheme 1) (Barry et al., 1988). The coupling between PEP mutase and P-pyr decarboxylase has now been demonstrated in vitro using purified mutase and partially purified decarboxylase. If the number of units of PEP mutase and of P-pyr decarboxylase activity measured for the $T$. pyriformis cellular homogenate in this study is an accurate reflection of the number of units of activity existing in the whole cell, then we estimate that the activity ratio of the these two enzymes in vivo is $c a$. 6:1. This comparison does not, however, take into account the fraction of the two enzymes bound to the substrate under cellular conditions nor the possible operation of facilitated substrate diffusion between mutase and decarboxylase active sites. These issues must be addressed in future studies.

A Test for Formation of a Phosphoryl Enzyme Intermediate in the PEP Mutase Reaction. The PEP mutase catalyzed rearrangement of PEP to P-pyr occurs via a stepwise transfer of the phosphoryl group from the $\mathrm{C}(2)$ oxygen to the $\mathrm{C}(3)$ (Seidel et al., 1990; McQueney et al., 1991). The present study was carried out for the purpose of determining if the mutase employs a form of covalent catalysis in which a nucleophilic active site amino acid side chain abstracts the PEP phosphoryl group and then adds it to the $\mathrm{C}(3)$ of the resulting pyruvyl enolate anion. Our failure to detect the formation of a phosphoenzyme intermediate in earlier transient kinetic studies (McQueney, 1991) prompted us to seek a different experimental approach in which the PEP analog, oxalyl phosphate, serves as an alternate substrate for the mutase. Previous studies have shown that oxalyl phosphate functions as substrate in place of PEP for all three of the enzymes which have been tested: pyruvate kinase, pyruvate phosphate dikinase (PPDK), and PEP carboxykinase (Kofron \& Reed, 1990). Oxalyl phosphate, like PEP, possesses a high phosphoryl group transfer potential (Kofron \& Reed, 1990). Whereas phosphoryl transfer from PEP produces a high-energy pyruvyl enolate anion, phosphoryl transfer from oxalyl phosphate yields oxalate, a stable compound. The high affinity that oxalate has for the active sites of the PEP-dependent enzymes listed above, including the PEP mutase, is attributed to its structural similarity to the enolate dianion of pyruvate. Thus, phosphoryl transfer from oxalyl phosphate to the active site catalytic residue of PEP mutase will produce E-P•oxalate $\cdot \mathrm{Mg}$, a complex that, in principle, should be easily detected.

In the first set of experiments synthetic $\left[{ }^{32} \mathrm{P}\right]$ oxalyl phosphate was employed so that we might detect formation of the E-P•oxalate $\cdot \mathrm{Mg}$ complex by measuring enzyme covalently radiolabeled with ${ }^{32} \mathrm{P}$. The feasibility of this approach was first demonstrated using PPDK as the catalyst for autophosphorylation. This enzyme catalyzes phosphoryl transfer from PEP to its own active site histidine residue as its first step in the catalysis of ATP formation from AMP, PEP, and inorganic pyrophosphate (Wood et al., 1977). Previous studies have shown that the formation of the E-P. pyruvyl enol(ate) $\cdot \mathrm{Mg}$ complex can be monitored during a single turnover on the enzyme by using $\left[{ }^{32} \mathrm{P}\right] \mathrm{PEP}$ as reactant and isolating the ${ }^{32} \mathrm{P}$-labeled enzyme precipitated from the acid/ $\mathrm{CCl}_{4}$-quenched reaction mixture (Carroll et al., 1989). An analogous procedure was used in the present study to examine a single turnover of [ $\left.{ }^{32} \mathrm{P}\right]$ oxalyl phosphate $(200 \mu \mathrm{M})$ by PPDK $(20 \mu \mathrm{M})$. The rate profile (percent of the total PPDK present that is radiolabeled vs reaction time) obtained for a single turnover on the enzyme is shown in Figure 1A for the $\mathrm{Mg}(\mathrm{II})$-activated enzyme and Figure $1 \mathrm{~B}$ for the Mn(II)-activated enzyme. Control reactions were carried out which employed acid-denatured enzyme in place of native 

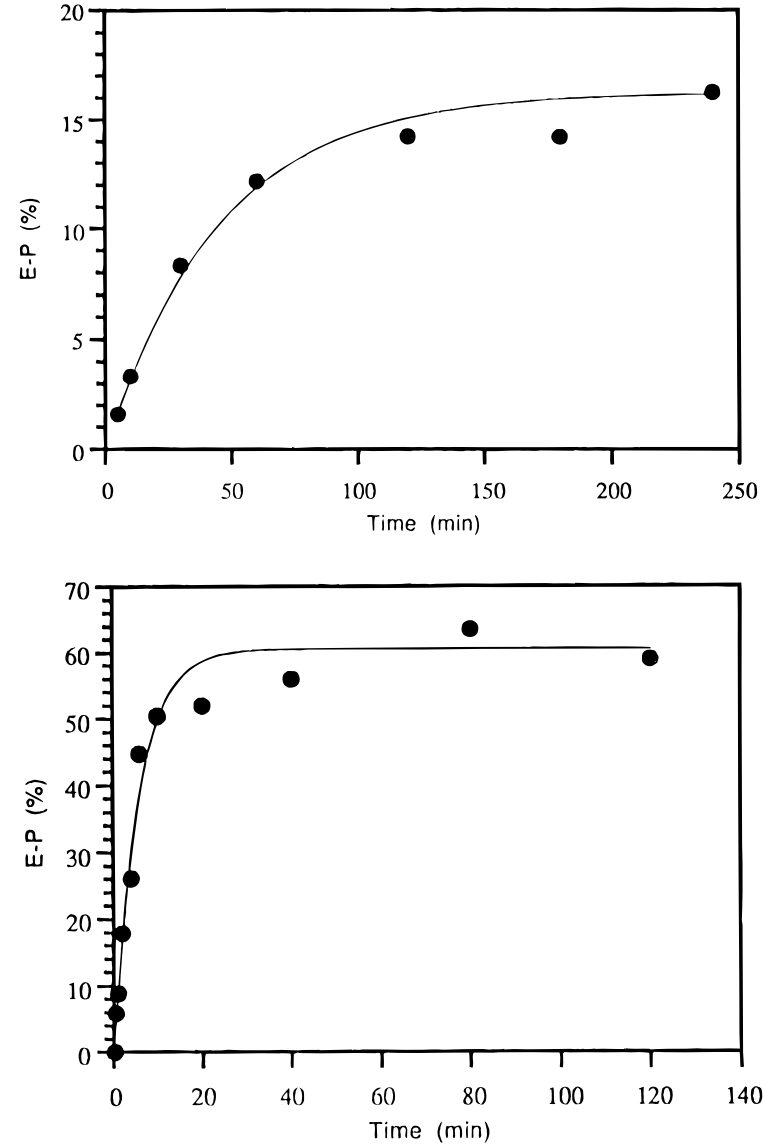

FIGURE 1: Time course for a single turnover of $\left[{ }^{32} \mathrm{P}\right]$ oxalyl phosphate in the active site of PPDK in which the fraction of PPDK radiolabeled (E-P) is plotted as a function of the reaction time. The initial reaction mixtures $\left(80 \mu \mathrm{L}, 25{ }^{\circ} \mathrm{C}\right)$ contained $200 \mu \mathrm{M}$ [32 P] oxalyl phosphate, $20 \mu \mathrm{M}$ PPDK, $20 \mathrm{mM} \mathrm{K}{ }^{+}$Hepes (pH 6.8), $75 \mathrm{mM} \mathrm{NH}_{4} \mathrm{Cl}$, and $0.44 \mathrm{mM} \mathrm{MgCl} 2$ (A, top) or $\mathrm{MnCl}_{2}$ (B, bottom). enzyme or which contained EDTA in excess of metal ion or which did not contain metal ion. None of the control reactions produced a detectable amount of ${ }^{32} \mathrm{P}$-radiolabeled enzyme. A computer fit of the data shown in Figure 1 to a first-order rate equation gave a $k_{\mathrm{cat}}=3.7 \times 10^{-4} \mathrm{~s}^{-1}$ and maximum level of labeling of $15 \%$ for the $\mathrm{Mg}(\mathrm{II})$-activated enzyme $^{3}$ and a $k_{\text {cat }}=2.9 \times 10^{-3} \mathrm{~s}^{-1}$ and maximum level of labeling of $60 \%$ for the $\mathrm{Mn}$ (II)-activated enzyme. These results serve as precedent for the formation and detection of a $\left[{ }^{32} \mathrm{P}\right] \mathrm{E}-\mathrm{P} \cdot \mathrm{oxalate} \cdot \mathrm{Mg}$ complex.

Next, the reaction of $\left[{ }^{32} \mathrm{P}\right]$ oxalyl phosphate $(200 \mu \mathrm{M})$ with the PEP mutase $(20 \mu \mathrm{M})$ was tested using $\mathrm{Mg}$ (II) or Mn(II) as cofactor in $20 \mathrm{mM}$ buffer $\left(\mathrm{K}^{+}\right.$Mes or $\mathrm{K}^{+}$Hepes $)$at $\mathrm{pH}$ 6.0, 7.0, and 7.6. The reactions were assayed for radiolabeled enzyme over 2-30 min incubation periods using the method described above for PPDK. No ${ }^{32} \mathrm{P}$-labeled enzyme was detected. On the basis of the specific activity of the $\left[{ }^{32} \mathrm{P}\right]-$ oxalyl phosphate $(42 \mu \mathrm{Ci} / \mu \mathrm{mol})$ and the quantity of enzyme $\left(1.6 \times 10^{-3} \mu \mathrm{mol}\right)$ used in these reactions, a $1 \%$ yield of radiolabeled enzyme is expected to generate $c a .1000 \mathrm{cpm}$ in the enzyme fraction. Since the ${ }^{32} \mathrm{P}$ content of the enzyme pellets obtained from the quenched mutase $/\left[{ }^{32} \mathrm{P}\right]$ oxalyl phosphate reactions did not exceed background $(30 \mathrm{cpm})$, the yield of ${ }^{32} \mathrm{P}$-labeled mutase obtained from this procedure is negligible.

${ }^{3}$ The rate observed for a single turnover of PEP under these reaction conditions is estimated at $150 \mathrm{~s}^{-1}$, and the percent enzyme phosphorylated is $50 \%$ (Mehl et al., 1994).
Failure to observe the formation of radiolabeled PEP mutase by reaction with the $\left[{ }^{32} \mathrm{P}\right]$ oxalyl phosphate calls into question, but does not disprove, the phosphoenzyme mechanism of Scheme 2. Two caveats are (i) that the mutase may not recognize the oxalyl phosphate as substrate and (ii) that the phosphorylated mutase may not be stable to the assay conditions employed in the experiment. In principle, mutasecatalyzed phosphoryl transfer in oxalyl phosphate can be tested by measuring positional isotope exchange in $\left[{ }^{18} \mathrm{O}_{4}\right]$ oxalyl phosphate. However, the chemical instability of oxalyl phosphate in aqueous solution precludes such a measurement from being made. Thus, the first caveat remains. The second caveat was addressed in this study by testing phosphoenzyme formation using noninvasive assay methods. The first of these employed gel filtration column chromatography at neutral $\mathrm{pH}$ to separate the mutase from reactant. Accordingly, the labeling reaction was repeated, and the reaction mixture (assayed at 10 and $60 \mathrm{~min}$ ) was promptly chromatographed on a small Sephadex G-25 gel filtration column at $4{ }^{\circ} \mathrm{C}$ with buffer at $\mathrm{pH}$ 7. Most phosphate ester, anhydride, and amide linkages are stable under these mild conditions. The column fractions were assayed for ${ }^{32} \mathrm{P}$ content and for PEP mutase activity. The elution profile revealed complete separation of the enzyme from the radioactive salt fraction (Figure 2, supporting information). The enzyme fractions were not, however, radioactive, thus indicating that the PEP mutase had not been phosphorylated by the $\left[{ }^{32} \mathrm{P}\right]$ oxalyl phosphate.

Lastly, we attempted to detect the formation of the E-P. oxalate $\cdot \mathrm{Mg}$ complex in situ by measuring PEP mutase inhibition by oxalyl phosphate. Specifically, if the binding of the oxalyl phosphate to the active site is followed by catalysis to form the E-P•oxalate $\cdot \mathrm{Mg}$ complex, the rate profile of the mutase-catalyzed P-pyr reaction measured in the presence of the oxalyl phosphate should be biphasic with the initial phase dominated by inhibition of the native enzyme by oxalyl phosphate and the second phase dominated by inhibition of the phosphoryl enzyme by oxalate. The latter inhibition is expected to be orders of magnitude stronger than the former. This expectation is based on the theory that an enzyme binds its intermediates and transition states more strongly than it does its substrates and products (Albery \& Knowles, 1976). In the present case, the E•oxalyl phosphate• $\mathrm{Mg}$ complex is the analog of the E.PEP.Mg complex, and the E-P.oxalate $\mathrm{Mg}$ complex is the analog of the putative intermediate, E-P·pyruvyl enolate $\cdot \mathrm{Mg}$. The dissociation constant of the E.PEP. $\mathrm{Mg}$ complex (based on the $K_{\mathrm{i}}$ of PEP as a competitive, product inhibitor vs P-pyr) was reported by Seidel and Knowles (1994) to be $350 \mu \mathrm{M}$. Oxalate, on the other hand, inhibits the apoenzyme with a $K_{\mathrm{i}}=25 \mu \mathrm{M}$ (Seidel \& Knowles, 1994) or $K_{\mathrm{i}}=32 \mu \mathrm{M}$ as determined in the present study. The $K_{\mathrm{i}}$ for oxalate inhibition of the phosphoenzyme is expected to be less than $1 \mu \mathrm{M}$. This estimate is derived from the $K_{\mathrm{i}}$ values measured for oxalate inhibition of pyruvate kinase [ $6 \mu \mathrm{M}$ for the apoenzyme (Reed $\&$ Morgan, 1974) and $0.07 \mu \mathrm{M}$ for the ATP complex (Reed, personal communication of unpublished data)] and PPDK [700 $\mu \mathrm{M}$ for the apoenzyme and $0.1 \mu \mathrm{M}$ for the phosphorylated enzyme (Thrall \& Dunaway-Mariano, 1994)]. However, when we tested freshly prepared oxalyl phosphate as a competitive inhibitor of the mutase vs P-pyr, we observed the loose binding predicted for oxalyl phosphate $\left(K_{\mathrm{i}}=180\right.$ $\pm 10 \mu \mathrm{M}$ ) but not the tight binding predicted to result from 
the formation of the E-P•oxalate $\cdot \mathrm{Mg}$ complex.

Together, these results suggest that the mutase does not catalyze its own phosphorylation with oxalyl phosphate. This may reflect the fact that the mutase-catalyzed reaction of the natural substrate, PEP, does not proceed via a phosphoenzyme intermediate or simply that the mutase does not recognize oxalyl phosphate as substrate. The instability of oxalyl phosphate toward hydrolysis in aqueous solution (Kofron \& Reed, 1990) precluded its use in the single turnover reactions to detect the intermediates of the dissociative pathway, metaphosphate and pyruvyl enolate, since they are captured as orthophosphate and pyruvate, respectively. Thus, the experimental results presented in this paper do not rule out the possibility that the PEP mutase reaction proceeds via a phosphoenzyme intermediate. They do, however, introduce a new uncertainty. Future mechanistic studies of this enzyme in our laboratory will test the dissociative pathway for catalyzed intramolecular phosphoryl transfer in PEP.

\section{ACKNOWLEDGMENT}

The technical editing of the manuscript by Ms. Pauli Kosclskey is gratefully acknowledged.

\section{SUPPORTING INFORMATION AVAILABLE}

A description of the preparation of $\left[{ }^{32} \mathrm{P}\right]$ oxalyl phosphate free of orthophosphate and oxalate, Figure 1 showing elution profiles of mixtures of oxalyl phosphate, oxalate, and phosphate chromatographed on AG1-X8 200-400 anionexchange columns, and Figure 2 showing the elution profile of the Sephadex G-25 column $(1.3 \mathrm{~cm} \times 60 \mathrm{~cm})$ chromatography of an $80 \mu \mathrm{L}$ reaction solution of $20 \mu \mathrm{M}$ PEP mutase with $200 \mu \mathrm{M}\left[{ }^{32} \mathrm{P}\right.$ ]oxalyl phosphate (4 pages). Ordering information is given on any current masthead page.

\section{REFERENCES}

Albery, W. J., \& Knowles, J. R. (1976) Biochemistry 14, 5631.

Anderson, V. E., Weiss, P. M., \& Cleland, W. W. (1984) Biochemistry 23, 2779.

Barry, R. J., Bowman, E., McQueney, M., \& Dunaway-Mariano, D. (1988) Biochem. Biophys. Res. Commun. 153, 177.

Bowman, E., McQueney, M., Barry, R. J., \& Dunaway-Mariano, D. (1988) J. Am. Chem. Soc. 110, 5575.

Bowman, E., McQueney, M., Scholten, J. D., \& Dunaway-Mariano, D. (1990) Biochemistry 29, 7061.

Bradford, M. M. (1976) Anal. Biochem. 72, 248.

Carroll, L. J., Mehl, A. F., \& Dunaway-Mariano, D. (1989) J. Am. Chem. Soc. 111, 5965.

Chavane, M. V. (1947) C. R. Acad. Sci. 224, 406

Cleland, W. W. (1979) Methods Enzymol. 63, 103.

Hammerschmidt, F., \& Kahlig, H. (1991) J. Org. Chem. 56, 2364.

Hara, O., Murakami, T., Imai, S., Anzai, H., Itoh, R., Kumada, Y., Takano, E., Satoh, E., Satoh, A., Nakaoka, K., \& Thompson, C. (1991) J. Gen. Microbiol. 137, 351.

Hidaka, T., Mori, M., Imai, S., Hara, O., Nagaoka, K., \& Seto, H. (1989) J. Antibiot. (Tokyo) 42, 491.

Hidaka, T., Iwakura, H., Imai, S., \& Seto, H. (1992) J. Antibiot. (Tokyo) 45, 1008.

Hilderbrand, R. L. (1983) The Role of Phosphonates in Living Systems, CRC Press, Boca Raton, FL.
Hilderbrand, R. L., Curley-Joseph, J., Lubansky, H. J., \& Henderson, T. O. (1983) in Topics in Phosphorus Chemistry (Grayson, M., \& Griffith, E., Eds.) Vol. 11, p 297, Wiley-Interscience, New York.

Hori, T. Horiguchi, M., \& Hayshori, A. (1994) in Biochemistry of Natural C-P Compounds, Maruzen, Tokyo.

Horiguchi, M. (1972) Biochim. Biophys. Acta 261, 102.

Horiguchi, M., \& Kandatsu, M. (1959) Nature (London) 184, 901.

Janc, J. J., O'Leary, M. H., \& Cleland, W. W. (1992) Biochemistry 31,6421 .

Kamigiri, K., Hidaka, T., Imai, S., Murakami, T., \& Seto, H. (1992) J. Antibiot. 45, 781.

Kim, J. (1994) Ph.D. Thesis, University of Maryland, College Park, MD.

Kofron, J. L., \& Reed, G. H. (1990) Arch. Biochem. Biophys. 280, 40-44.

Kofron, J. L.,Ash, D. E., \& Reed, G. H. (1988) Biochemistry 27, 4781.

Kuzuyama, T., Hidaka, T., Kamikiri, K., Imai, S., \& Seto, H. (1992) J. Antibiot. 45, 1812.

LaNauze, J. M., Coggins, J. R., \& Dixon, H. B. F. (1977) Biochem. J. 165, 409.

Mastelerz, P. (1984) in Natural Products Chemistry (Zulewski, R. I., \& Skolik, J. J., Eds.) p 171, Elsevier Science Publishers B. V., Amsterdam.

McQueney, M. (1991) Ph.D. Thesis, University of Maryland, College Park, MD.

McQueney, M. S., Lee, S.-L., Swartz, W. H., Ammon, H. L., Mariano, P. S., \& Dunaway-Mariano, D. (1991) J. Org. Chem. 56,7121

Mehl, A. F. , Xu, Y., \& Dunaway-Mariano, D. (1994) Biochemistry 33, 1093.

Michaels, G., Milner, Y., \& Reed, G. H. (1975) Biochemistry 14, 3213.

Mildvan, A. S., Scrutton, M. C., \& Utter, M. F. (1966) J. Biol. Chem. 241, 3488.

Nova, W. B., Winer, A. D., Glaid, A. J., \& Schwert, G. W. (1959) J. Biol. Chem. 234, 1143.

Olsen, D. B., Hepburn, T. W., Moos, M., Mariano, P. S., \& Dunaway-Mariano, D. (1988) Biochemistry 27, 2229.

Pocalyko, D. J. (1990) Ph.D. Thesis, University of Maryland, College Park, Md.

Pollack, S. J., Freeman, S., Pompliano, D. L., \& Knowles, R. (1992) Eur. J. Biochem. 209, 735.

Reed, G. H., \& Morgan, S. D. (1974) Biochemistry 13, 3537.

Schmitt, A., Botke, I., \& Siebert, G. (1966) Z. Physiol. Chem. 347, 18.

Schwalbe, C. H., \& Freeman, S. (1990) J. Chem. Soc., Chem. Commun., 251.

Seidel, H. M., \& Knowles, J. R. (1994) Biochemistry 33, 5641.

Seidel, H. M., Freeman, S., Seto, H., \& Knowles, J. R. (1988) Nature (London) 335, 457.

Seidel, H. M., Freeman, S., Schwalbe, C. H., \& Knowles, J. R. (1990) J. Am. Chem. Soc. 112, 8149.

Seidel, H. M., Pompliano, D., \& Knowles, J. R. (1992) Biochemistry $31,2598$.

Seto, H. (1986) in Mycotoxins and Phycotoxins (Stein, P. S., \& Vleggaar, R., Eds.) p 77, Elsevier Science Publishers B. B., Amsterdam.

Seto, H., Hidaka, T., Kuzuyama, T., Shibahara, S., Usui, T., Sakanaka, O., \& Imai, S. (1991) J. Antibiot. 44, 1286.

Sparkes, M. J., Rogers, K. L., \& Dixon, B. F. (1990) Eur. J. Biochem. 194, 373.

Wood, H. G., O'Brien, W. E., \& Micheals, G. (1977) Adv. Enzymol. Relat. Areas Mol. Biol. 45, 85.

BI952944K 